\title{
Nassella tenuissima (Gramineae) recorded from Australia, a potential new weed related to Serrated Tussock
}

\author{
S.W.L. Jacobs, J. Everett and María Amelia Torres
}

\begin{abstract}
Jacobs, S.W.L. ${ }^{1}$, Everett, J. ${ }^{1}$ and Torres, Maria Amelia ${ }^{2}$ ('National Herbarium of New South Wales, Royal Botanic Gardens, Sydney NSW 2000, Australia; ${ }^{2}$ Departamento Científico de Plantas Vasculares, Museo de La Plata, Paseo del Bosque s/No., 1900 La Plata, Argentina) 1998. Nassella tenuissima (Gramineae) recorded from Australia, a potential new weed related to Serrated Tussock. Telopea 8(1): 41-46. Nassella tenuissima is recorded from the horticultural trade in New South Wales. It is very similar to $N$. trichotoma (Serrated Tussock) and difficult to distinguish from that species. It is possible that $N$. tenuissima has already become naturalised in Australia although not yet recorded. A description is provided of $N$. tenuissima and the distinguishing features of the two species are listed. The history of establishment of $N$. tenuissima in New Zealand is reviewed; comments are made on its cultivation in California; its potential weediness in Australia is assessed, and recommendations are made.
\end{abstract}

\section{Introduction}

Through the alertness of Ken Folkes, Weeds Officer for the Snowy River Shire Council, a cultivated specimen he thought suspiciously similar to Serrated Tussock (Nassella trichotoma (Nees) Hack. ex Arechav.) was forwarded to Jim Dellow of NSW Agriculture at Orange. The specimen was grown to flowering there in a glasshouse and forwarded for our comments.

The specimen was then sent to Maria Amelia Torres in Argentina who identified it as Nassella tenuissima (Trin.) Barkworth.

Nassella tenuissima is native to New Mexico, Texas, Mexico, Argentina and Chile, has been cultivated in California and New Zealand, and also has been recorded from South Africa (Connor \& Ford 1996) where it is apparently only known from one locality (N. Barker, pers. comm.).

Nassella tenuissima is closely related to N. trichotoma (Serrated Tussock), a serious pasture and environmental weed in temperate Australia, and looks so similar, especially when not flowering, that it could be mistaken in the field for N. trichotoma. We thought it advisable to assess the potential seriousness of $N$. tenuissima as a weed in Australia and to provide the information required for its detection and the documentation of its behaviour.

\section{Nassella tenuissima}

The species can only be distinguished from Serrated Tussock when flowering. N. tenuissima differs from Serrated Tussock in:

(i) its inflorescence (seedhead) not always being fully exserted and spread from the sheath at maturity; 
(ii) the seedhead apparently not detaching from the uppermost culm node at maturity (these characters require more observations over a range of conditions);

(iii) awns 5-9 cm long (2-3.5 cm in Serrated Tussock);

(iv) the lower glume slightly longer (9-10.5 $\mathrm{mm}$ vs $6-8.5 \mathrm{~mm})$; (v) the body of the lemma slightly longer (to $3 \mathrm{~mm}$ vs $2 \mathrm{~mm}$ );

(vi) and the floret slightly less gibbous (i.e., less asymmetrical).

The key to species of Nassella in Jacobs and Everett (1993) can be modified to produce a key to all the species of Nassella recorded from Australia:

1 Summit of the lemma without a cylindrical corona; floret $<3.5 \mathrm{~mm}$ long

$1^{*}$ Summit of the lemma forming a conspicuous cylindrical corona 0.5-2.5 mm long around the base of the awn; floret $>3.5 \mathrm{~mm}$ long

2 Awn 2-3.5 cm long; floret 1.5-2 mm long; inflorescence fully exserted and detaching at maturity

N. trichotoma

2* Awn 4.5-9 cm long; floret 2-3 mm long; inflorescence often only partly exserted from sheath, detaching or not detaching at maturity N. tenuissima

3 Floret c. $4 \mathrm{~mm}$ long; awn 3.5 $-4 \mathrm{~cm}$ long, column scabrous with hairs $<0.05 \mathrm{~mm}$ long N. hyalina

3* Floret 5.5-10 mm long; awn 4.5-8.5 cm long, column scabrous or pubescent with hairs usually c. $0.2 \mathrm{~mm}$ long ........................................................................................ 4

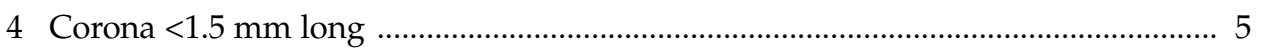

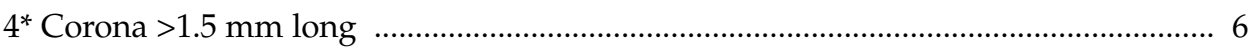

5 Lower glume 8-10 mm long; floret 5.5-6 mm long; coronal spines c. $0.1 \mathrm{~mm}$ long N. megapotamia

5* Lower glume 14-18 mm long; floret 6-10 mm long; coronal spines c. $0.5 \mathrm{~mm}$ long N. neesiana

6 Corona 1.5-2.5 mm long, with a firm basal part 0.5-1 $\mathrm{mm}$ long, the upper membranous part with hairs $1-1.5 \mathrm{~mm}$ long N. leucotricha

$6^{*}$ Corona $>3 \mathrm{~mm}$ long, with a firm basal part c. $3 \mathrm{~mm}$ long, the upper $0.5-1.9 \mathrm{~mm}$ lacerate into narrow fingers, these in turn lacerate at the apex into fine hairs $0.5 \mathrm{~mm}$ long .

N. charruana

*Nassella tenuissima (Trin.) Barkworth (1990: 612); Torres (1997: 37).

Basionym: Stipa tenuissima Trinius (1836: 67); Caro (1966: 62-65).

Holotype: Argentina: Mendoza, Gillies (LE).

Densely caespitose perennial with very numerous, often sterile, intravaginal innovations and wiry roots, the tussocks to $70 \mathrm{~cm}$ tall. Culms 2-4-noded, the nodes not thickened; internodes terete, smooth, glabrous. Sheaths tight around the culms or open towards the base of the plant, lightly striate, glabrous and smooth except for the more or less scaberulous margins. Ligule opaque, chartaceous, obtuse or truncate, 0.5-2.5 mm long, usually glabrous and smooth, symmetrical or asymmetrical. Blades straight or curving, convolute-filiform, setaceous, to c. $60 \mathrm{~cm}$ long, $0.25-0.5 \mathrm{~mm}$ diam., 
the outer surface minutely and distantly scaberulous, not striate. Inflorescence contracted and at first more or less included in the upper sheath*, with few spikelets towards the tips of the ultimate branches, $15-25 \mathrm{~cm}$ long, green or purplish from the colour of the glumes, the main axis somewhat compressed and plano-convex, antrorsely scabrous on the edges; branches filiform, 2-3 together, scabrous-pubescent, the lower up to $10 \mathrm{~cm}$ long, unequally branched, with spikelets borne on the ultimate branchlets on long capillary pedicels. Spikelets narrowly lanceolate, 5-10 mm long (excluding awn). Glumes much longer than the floret, unequal, narrowly lanceolate, long-acuminate with a hair-like tip, 3-nerved with the lateral nerves shorter and converging towards the median nerve, membranous and often purple, the apex thinly hyaline; lower glume 8-10 $\mathrm{mm}$ long, upper glume 5-7 $\mathrm{mm}$ long. Floret ellipsoid to obovate, gibbous, slightly compressed, without a corona, 2-3 $\mathrm{mm}$ long (excluding awn), c. $1 \mathrm{~mm}$ wide. Lemma obscurely 5-nerved, antrorsely scabrous upwards, strawcoloured, green or purplish, with an excentric filiform awn, the margins overlapping and tightly enclosing the palea; awn more or less straight or flexuose, 5-9 cm long, slightly twisted in the lower part, minutely scabrous, inconspicuously articulate with the lemma, rather tardily deciduous; callus shortly oblique, obtuse or minutely pointed, with white, erect, divergent hairs to $1.5 \mathrm{~mm}$ long. Palea thinly hyaline, glabrous, nerveless, $30-50 \%$ as long as the lemma. Lodicules 2, thinly hyaline, glabrous, nerveless, $0.25-0.75 \mathrm{~mm}$ long. Stamens 3, sometimes all c. $1 \mathrm{~mm}$ long and mostly all exserted though sometimes not exserted; sometimes with a single anther 0.6-1.5 mm long and 2 c. $0.4 \mathrm{~mm}$ long or less, either all exserted, or sometimes the 2 smaller (?and sometimes the 3rd) not exserted. Caryopsis ellipsoid, slightly compressed, 2-2.5 mm long; hilum linear, straight, inconspicuous, c. $60-70 \%$ of grain length; embryo c. $50 \%$ grain length.

* Many species of the Stipeae are facultatively cleistogamous (Vickery et al. 1986) and the behaviour of the florets can be influenced by prevailing conditions. There is evidence of both cleistogamy and chasmogamy in N. tenuissima (Connor \& Ford 1996, 1997). Both types of flower are in the same inflorescence. Cleistogamous flowers are more precocious than the chasmogamous flowers and mature earlier. The only specimen from Australia has partly exserted inflorescences, as seems to be the case in New Zealand specimens, whereas there are reports of more exserted inflorescences in Argentina (Connor \& Ford 1996, 1997) though the lower part of the inflorescence is always recorded as enclosed by the sheath. It is not yet clear whether any of these inflorescences becomes detached before the spikelets disarticulate.

\section{Natural distribution in Argentina}

In Argentina it grows in the Central, Western, Southern and Northwestern regions, extending from about $26^{\circ} 50^{\prime} \mathrm{S}$ to $47^{\circ} 34^{\prime} \mathrm{S}$, and from near sea level to about $2900 \mathrm{~m}$ altitude. Typical habitats include some zones of the 'Pampeana' grass steppe, Patagonian grass and shrub steppe, ground cover in various xeromorphic and semiarid woodlands (e.g. the Calden woodlands of Prosopis caldenia Burk.), and highland and, sometimes, alpine meadows. It is a species with a wide climatic and habitat range.

\section{Natural distribution and cultivation in USA}

In Texas, N. tenuissima is reported (Hitchcock \& Chase 1951; Correll \& Johnston 1970; Martin \& Hutchins 1980; Connor \& Ford 1996, 1997) from open rocky flats and slopes, on mountains, plateaux and arid valleys with an average rainfall of $300 \mathrm{~mm}$, with soils and sites of extreme variability. In the southern United States it grows over an altitude range of 600-2350 m (M.E. Barkworth pers. com.). In Texas and New Mexico it is 
apparently eaten by cattle and goats but, in California, has proved difficult to eradicate after spreading from cultivation (M.E. Barkworth pers. com.). It should be noted that N. trichotoma is reportedly eaten by stock in South America (Vickery \& Jacobs 1980).

\section{History in New Zealand}

It is fortunate that this is one of those rare occasions where the establishment of a potential weed species has been well documented. Ford (1994) documented the first recording of its spread from cultivation in New Zealand in a commercial nursery and noted that it was not included in the treatment of stipoid grasses in New Zealand (Jacobs et al. 1989). Gardner et al. (1996) supplied the first published identification, reported a second locality of naturalisation and predicted that it would soon be widespread. Connor and Ford $(1996,1997)$ reviewed the situation, including recent changes in the classification and nomenclature in the stipoid grasses and pleaded for vigilance in recording all introduced stipoid species. De Lange and Gardner (1997) despairingly documented the continued spread of the species, both from known sites and from previously unrecorded sites, and the apparent lack of action by both responsible authorities and the nursery industry.

It appears that $N$. tenuissima was originally imported as Stipa tenuissima (a synonym of $N$. tenuissima) in mistake for the long-cultivated Stipa tenacissima (now Achnatherum tenacissima Barkworth; Barkworth 1993; Jacobs \& Everett 1996), Esparto Grass.

\section{History in Australia}

The origin of the Australian material is still not entirely clear but the letter from Ken Folkes accompanying the first specimen noted:

'Recently I received an ornamental grass which had been purchased several years ago by a friend, from a Sydney nursery.'

The letter continues:

'This plant is marketed as a native grass, and was called "Elegant Spear Grass".'

Elegant Spear Grass, Austrostipa elegantissima (Labill.) Jacobs and Everett, is indeed native and, as the name implies, is also a very attractive horticultural subject. It bears no similarity to the recent introduction though it is in a related genus. It appears that $N$. tenuissima was (?is) marketed under a wrong and misleading name, an action that could prove to have dire consequences.

It seems most likely that the Australian material was imported from either California or New Zealand, with perhaps the latter being more likely. It is possible that this importation was made before the potential problems had been identified in New Zealand and California. The fact that N. tenuissima was apparently sold in Australia incorrectly labelled with the common name of an Australian native species may indicate that this was not the case.

Although not recorded as naturalised within Australia, it is indistinguishable vegetatively from Serrated Tussock and will only be recognised as distinct when flowering and when observers have been made aware of the differences between the two species.

While it is probably important to try and identify how $N$. tenuissima was introduced to prevent a similar event being repeated, it is more important to document whether this species has already become naturalised in Australia and to try to eradicate any such plants, and to remove plants from propagation, sale and cultivation. 


\section{Assessment of potential weediness}

In its natural habitat, $N$. tenuissima grows from about $20^{\circ}$ to $35^{\circ}$ North, and from $25^{\circ}$ to $47^{\circ}$ South, in areas with an average annual rainfall of $300 \mathrm{~mm}$, and on extremely variable soils. Reports from Wellington, New Zealand, suggest that the climate there is too wet for it, Ford (1994) suggesting an upper rainfall limit of $<1250 \mathrm{~mm}$. Even a very rough transfer of this information on to a map of Australia suggests that, all else being equal (which it never is), $N$. tenuissima could become established over about $65 \%$ of New South Wales (excluding the coastal strip and the northwest corner), $70 \%$ of Victoria (excluding the higher rainfall areas), the southern $20 \%$ of South Australia, 20\% of Tasmania, up to $20 \%$ of Western Australia (the southwest corner), and possibly some of the higher country or even elsewhere in southern Queensland. Whether it becomes a serious weed in all or any of these areas will depend on various as yet unknown biological characteristics and the particular land management regimes. Although it is reportedly eaten by stock in its native range (M.E. Barkworth pers. comm.), so is Serrated Tussock in its native range (Vickery \& Jacobs 1980). The story of Eragrostis curvula (African Love Grass) is also pertinent (Jacobs 1982) where palatability varies within a species and can be dependent on the alternatives available. The story in southern Africa for E. curvula was very different from that observed here.

Some consolation may also be taken by the apparent lack of long distance wind dispersal in N. tenuissima but, as noted above, this is not definitely proved, and de Lange and Gardner (1997) document establishment at sites in New Zealand apparently well away from known plantings.

The information available suggests that $N$. tenuissima is potentially a serious weed. We recommend that:

(i) N. tenuissima be banned from propagation and sale, and that nursery stocks be destroyed;

(ii) N. tenuissima be removed where cultivated in public areas;

(iii) private land owners be encouraged to remove N. tenuissima from gardens;

(iv) experienced Weeds Officers be taught the differences between $N$. tenuissima and $N$. trichotoma and asked to look for N. tenuissima as opportunities arise; and

(v) the situation be monitored and assessed as data become available.

\section{Acknowledgments}

We thank Ewen Cameron for providing us with relevant references from New Zealand, Mary Barkworth for information about the species in North America, Nigel Barker for information about the species in South Africa, and Jim Dellow for providing the first good specimen.

\section{References}

Barkworth, M.E. (1990) Nassella (Gramineae, Stipeae): revised interpretation and nomenclatural changes. Taxon 39: 597-614.

Barkworth, M.E. (1993) North American Stipeae (Gramineae) taxonomic changes and other comments. Phytologia 74: 1-25.

Caro, J.A. (1966) Las especies de Stipa (Gramineae) de la región Central Argentina. Kurtziana 3: 7-119. 
Connor, H.E. \& Ford, K. (1996) Stipa tenuissima, and name changes in stipoid grasses. Weed Identification News No. 20: 1-5.

Connor, H.E. \& Ford, K. (1997) Stipa tenuissima, and name changes in stipoid grasses. New Zealand Botanical Society Newsletter 47: 10-13.

Correll, D.S. \& Johnston, M.C. (1970) Manual of the Vascular Plants of Texas. (Texas Research Foundation: Renner).

de Lange, P.J. \& Gardner, R.O. (1997) Stipa tenuissima: unwanted weedy grass on the move. Auckland Botanical Society Journal 52: 25-26.

Ford, K. (1994) Stipa sp., Nassella Tussock relation: “a potential weed!" Weed Identification News No. 13: $3-5$.

Gardner, R.O., Champion, P.D. \& Lange, P.J. de (1996) Andropogon virginicus and Stipa tenuissima. Auckland Botanical Society Journal 51: 31-33.

Hitchcock, A.S. \& Chase, A. (1951) Manual of the grasses of the United States. United States Department of Agriculture Miscellaneous Publication no. 200. (Govt. Printing Office: Washington)

Jacobs, S.W.L. (1982) Classification of the Eragrostis curvula complex in Australia. Australian Plant Introduction Review 15: 5-14.

Jacobs, S.W.L. \& Everett, J. (1993) Nassella. Pp. 638-639 in Harden, G.J. (ed.), Flora of New South Wales, vol. 4. (New South Wales University Press: Sydney)

Jacobs, S.W.L. \& Everett, J. (1996) Austrostipa, a new genus, and new names for Australian species formerly included in Stipa (Gramineae). Telopea 6: 579-595.

Jacobs, S.W.L., Everett, J., Connor, H.E., \& Edgar, E. (1989) Stipoid grasses in New Zealand. New Zealand Journal of Botany 27: 569-582.

Martin, W.C. \& Hutchins, C.R. (1980) A Flora of New Mexico, vol. 1. (J. Cramer: Vaduz).

Torres, M.A. (1997) Nassella (Gramineae) del noroeste de la Argentina. Monogr. Comis. Invest. Ci. Prov. Buenos Aires 13: 5-45.

Vickery, J.W. \& Jacobs, S.W.L. (1980) Nassella and Oryzopsis in New South Wales. Telopea 2: 17-23.

Vickery, J.W., Jacobs, S.W.L. \& Everett, J. (1986) Taxonomic studies in Stipa (Poaceae). Telopea 3: $1-132$. 